\title{
PENINGKATAN KETERAMPILAN BERPIKIR KRITIS PADA PEMBELAJARAN GEOMETRI DENGAN PENDEKATAN PENDIDIKAN MATEMATIKA REALISTIK DI KELAS IV SDN 1 PULE KECAMATAN PULE KABUPATEN TRENGGALEK
}

\author{
Yuni Anjarwati ${ }^{1}$, Siti Maghfirotun Amin $^{2}$, Agung Lukito ${ }^{3}$ \\ Pendidikan Dasar Pascasarjana Universitas Negeri Surabaya
}

\begin{abstract}
Abstrak
Penelitian ini bertujuan untuk meningkatkan keterampilan berpikir kritis pada pembelajaran geometri dengan pendekatan Pendidikan Matematika Realistik (PMR) di kelas IV SDN 1 Pule Kecamatan Pule Kabupaten Trenggalek.

Penelitian ini merupakan Penelitian Tindakan Kelas (PTK) yang dilaksanakan dalam dua siklus. Tiap siklus terdiri atas empat tahap; yaitu, tahap perencanaan, aksi/tindakan, observasi, dan refleksi. Instrumen yang digunakan adalah Tes Keterampilan Berpikir Kritis (TKBK), Tes Hasil Belajar (THB), lembar observasi aktivitas guru dan peserta didik, serta angket respon peserta didik. Data hasil penelitian dianalisis secara deskriptif kuantitatif.

Hasil penelitian menunjukkan bahwa: (1) aktivitas guru dalam Kegiatan Belajar Mengajar (KBM) meningkat, yakni $91,8 \%$ pada siklus I menjadi $94,7 \%$ pada siklus II; (2) aktivitas peserta didik dalam KBM meningkat dari 78,5\% pada siklus I menjadi 85,0\% pada siklus II; (3) keterampilan berpikir kritis peserta didik meningkat dari $53,0 \%$ pada studi awal menjadi $61,0 \%$ pada siklus I, dan kembali meningkat menjadi 76,4\% pada siklus II; (4) hasil belajar peserta didik meningkat dari $74,0 \%$ pada siklus I menjadi $86,5 \%$ pada siklus II; serta (5) terjadi interaksi aktif dalam KBM, guru mengajar sesuai dengan langkah-langkah dalam RPP, dan peserta didik memberikan respon positif terhadap proses belajar mengajar beserta perangkat pembelajaran yang dirancang. Berdasarkan analisis data dapat disimpulkan bahwa penerapan pendekatan PMR pada pembelajaran geometri dapat meningkatkan keterampilan berpikir kritis peserta didik di kelas IV SDN 1 Pule Kecamatan Pule Kabupaten Trenggalek. Peningkatan tersebut ditunjukkan oleh peningkatan hasil tes keterampilan berpikir kritis mulai dari studi awal sampai siklus II.
\end{abstract}

Kata-kata kunci: keterampilan berpikir kritis, pembelajaran geometri, pendidikan matematika realistik (PMR).

\begin{abstract}
This research aims at improving students' critical thinking skills in learning geometry using Realistic Mathematics Education (RME) approach at Grade IV of SDN 1 Pule Subdistrict Pule District Trenggalek.

This research is a classroom action research conducted in two cycles. Each cycle consists of four phases; namely, planning, action, observation, and reflection. The instruments used were test of Critical Thinking Skills, achievement test, observation sheet for teacher and student activities, as well as the students' response questionnaire. Data were analyzed by quantitative descriptive methods.

The results showed that: (1) teacher activity in teaching and learning improved; namely, from 91,8\% in cycle I to $94,7 \%$ in cycle II; (2) students' activities in learning activities improved from $78,5 \%$ in cycle I to $85,0 \%$ in cycle II; (3) critical thinking skills of students improved from 53,0\% at the beginning of study to 61,0\% on cycle I, and again improved to 76,4\% in cycle II; (4) learning outcomes of students improved from 74,0\% in cycle I to $86,5 \%$ in cycle II; and (5) active interacty in learning, teacher taught according to the steps in the RPP, and the students responded positively to the learning process as well as learning materials being designed.

Based on data analysis it can be concluded that the implementation of Realistic Mathematics Education (RME) approach in learning geometry can improve students' critical thinking skills at Grade IV of SDN 1 Pule Subdistrict Pule District Trenggalek. The improvement is shown by the improvement in critical thinking skills test results from the initial study to cycle II.
\end{abstract}

Keywords: critical thinking skills, geometry learning, Realistic Mathematics Education (RME).

\section{PENDAHULUAN}

Salah satu cara mengisi kemerdekaan bangsa adalah meningkatkan pembangunan di segala bidang, salah satunya adalah bidang pendidikan, karena pendidikan merupakan modal utama dan mempunyai peranan penting dalam menyukseskan pembangunan nasional. Pendidikan adalah usaha sadar dan terencana untuk mewujudkan suasana belajar dan proses pembelajaran agar peserta didik secara aktif mengembangkan potensi dirinya untuk memiliki kekuatan spiritual keagaman, pengendalian diri, kepribadian, kecerdasan, akhlak 
mulia, serta ketrampilan yang diperlukan dirinya, masyarakat, bangsa, dan negara (pasal 1 UU RI No. 20 tahun 2003 tentang Sistem Pendidikan Nasional). Dalam hal ini sesuai dengan tujuan pendidikan nasional yaitu mencerdaskan kehidupan bangsa dan mengembangkan manusia seutuhnya.

Agar tujuan pendidikan nasional tersebut dapat dicapai, pemerintah mengupayakan untuk memperbaiki sistem pendidikan agar dapat meningkatkan mutu/kualitas pendidikan di Indonesia, yaitu dengan memperbaiki kurikulum yang ada. Perbaikan kurikulum ini menyesuaikan dengan keadaan peserta didik, kondisi lingkungan, dan potensi daerah. Oleh karena itu, guru harus berkualitas dan memiliki beberapa alternatif kegiatan pembelajaran yang sesuai dengan keadaan peserta didik, agar penalarannya dapat berkembang.

Salah satu mata pelajaran yang dapat digunakan untuk memperkuat penalaran peserta didik adalah mata pelajaran matematika. Dalam pembelajaran matematika pengembangan penalaran terjadi jika peserta didik diajak untuk berpikir atau membangun pemahaman konsep materi pelajaran yang sedang dipelajari.

Menurut Adam dan Hamm dalam Wijaya (2012:5-6) salah satu peran matematika bagi kehidupan adalah sebagai cara untuk berpikir, maka dapat dikatakan kamampuan berpikir/bernalar merupakan salah satu potensi yang harus dimiliki oleh peserta didik.

Akan tetapi, karena matematika menekankan pada kemampuan bernalar peserta didik, maka berpikir kritis (critical thinking) yang merupakan salah satu tingkatan berpikir (Soedjadi, 2007:21), dapat dikembangkan dalam kegiatan pembelajaran matematika, baik di tingkat SD, SLTP, maupun SLTA.

Hal ini sesuai dengan tujuan utama dari sekolah yaitu meningkatkan keterampilan/kemampuan peserta didik untuk berpikir kritis, membuat keputusan rasional, tentang apa yang diperbuat atas apa yang diyakini, seperti yang dinyatakan Ennis, 1998 dan Hitchcock, 1983 (dalam Nur, 2008:61). Selain itu, Ennis (2000:23) menyatakan bahwa berpikir kritis merupakan kemampuan esensial yang harus dimiliki peserta didik baik dalam menyelesaikan masalah ataupun mengambil keputusan dengan baik dan benar.

Jadi, dalam pembelajaran matematika keterampilan berpikir kritis dapat dikembangkan jika seorang peserta didik secara rutin dihadapkan pada suatu masalah, sehingga peserta didik tersebut terlatih untuk memecahkan masalah. Dengan demikian, keterampilan berpikir kritis perlu dilatihkan dan diterapkan dalam proses pembelajaran, karena melatih kemampuan bernalar peserta didik.

Berdasarkan hasil studi awal di SDN 1 Pule, ulangan harian matematika di semester satu ini menunjukkan bahwa lebih dari $62 \%$ pesera didik nilai matematikannya di bawah nilai standar, yaitu dibawah 60. Data yang lain juga menunjukkan bahwa hasil evaluasi atau ulangan harian pada materi geometri pada semester 2 kemarin/tahun lalu, juga menunjukkan hasil yang kurang memuaskan. Dari KKM yang telah ditentukan yaitu 65 , hanya sekitar 6 siswa yang mampu melampaui KKM dan selebihnya yaitu 26 siswa belum dapat mencapainya. Selain itu niali rata-rata matematika terendah dibandingkan dengan mata pelajaran yang lainnya. IPS nilai rata-ratanya 69 , Bahasa Indonesia 74, PKn 71, IPA 77, sedangkan matematika 62.

Setelah dilakukan pengkajian terhadap hasil belajar peserta didik tersebut, ternyata peserta didik lemah dalam hal mengerjakan soal cerita. Hal ini membuktikan bahwa peserta didik belum menunjukkan keterampilan berpikirnya terutama keterampilan berpikir kritis. Selaian itu, dalam kegiatan belajar mengajar gurunya masih menggunakan metode ceramah dengan pendekatan yang konvensional, yaitu kegitan pembelajaran dimana peserta didik hanya mendengarkan, mengikuti contoh, dan mengerjakan soal-soal latihan tanpa ikut terlibat dalam mengkontruksi konsep, prinsip atau struktur berdasarkan pemikiran sendiri. Hal inilah yang menyebabkan kegiatan pembelajaran tidak efektif, karena peserta didik kurang aktif dalam interaksi kegiatan pembelajaran, dan pada akhirnya peserta didik cenderung menghafal dan bekerja secara prosedural daripada menggunakan penalarannya untuk memahami matematika, sehingga peserta didik tidak memiliki kesempatan mengkontruksi pengetahuan matematikanya.

Kegiatan pembelajaran di atas tidak sejalan dengan psikologi kognitif yang banyak disarankan oleh para ahli, yakni informasi yang diperoleh dapat disimpan dalam memori jangka panjang peserta didik, sehingga peserta didik tidak pernah melupakan informasi yang didapat, karena mereka dapat menemukannya kembali dalam memorinya (Nur, 2008:16).

Jadi, guru hendaknya mampu menemukan cara terbaik agar peserta didik memahami berbagai 
konsep yang diajarkan, dengan harapan peserta didik dapat menggunakan dan mengingat konsep lebih lama serta mampu memahami materi pelajaran secara utuh (Djamarah, 2006:58), dengan mengidentifikasi kelemahan peserta didik dalam mengingat dan menggunakan kembali informasi serta pola pikir yang pernah dipelajari.

Guru tidak semata-mata memberikan pengetahuan kepada peserta didik, tetapi guru membantu peserta didik untuk membangun pengetahuan di dalam benaknya sendiri dengan cara mengajar yang menjadikan informasi bermakna dan relevan bagi peserta didik dan mengajak mereka secara sadar menggunakan strategi-strategi mereka sendiri untuk belajar (Trianto, 2011:13), sehingga peserta didik menjadikan informasi tersebut menjadi miliknya sendiri (Nur, 2008:2). Dengan demikian, dalam kegiatan pembelajaran guru membantu peserta didik untuk mengkontruksi pengetahuaannya agar peserta didik lebih memahami konsep yang sedang dipelajari.

Selain itu agar prestasi belajar matematika peserta didik berhasil seperti yang diharapkan, guru harus pandai memilih dan menentukan pendekatan pembelajaran yang akan diterapkan dalam kegiatan pembelajaran. Salah satu pendekatan pembelajaran yang dapat diterapkan dalam kegiatan pembelajaran tersebut adalah Realistic Mathematics Education $(R M E)$ atau yang dikenal di Indonesia dengan Pendidikan Matematika Realistik Imdonesia (PMRI). RME/PMRI dimasudkan untuk memulai pembelajaran matematika dengan cara mengaitkannya dengan situasi dunia nyata di sekitar peserta didik (Muhsetyo, 2011:1.16). Dengan harapan melalui pendekatan ini peserta didik tertarik terhadap materi pelajaran matematika, mudah menguasai konsep dan materi pelajaran namun tidak cepat lupa dengan apa yang telah diperolehnya, dan meningkatkan keterampilan berpikir, sehingga dapat meningkatkan prestasi belajarnya seperti yang terpampang dalam jurnal penelitian pendidikan Soviawati (2011).

Berdasarkan fakta di lapangan, geometri merupakan topik yang sulit dipahami peserta didik. Ini dapat dilihat dari banyaknya peserta didik yang duduk di kelas yang lebih tinggi belum mampu membedakan dan belum paham konsep geometri, sehingga mengalami kesulitan dalam mempelajari topik matematika yang lebih tinggi. Selain itu, karena belum matangnya pemahaman konsep geometri, peserta didik cenderung menghafalkannya.
Menurut Basman (dalam Anggraini, 2012) bahwa berpikir kritis dapat membantu peserta didik dalam meningkatkan pemahaman materi yang dipelajari dengan mengevaluasi secara kritis argumen pada buku teks, teman diskusi, dan argumen pendidik dalam pembelajaran. Jadi, jika peserta didik memiliki keterampilan berpikir ktitis, maka prestasi belajarnya akan bagus, karena peserta didik tersebut memahami konsep materi yang diajarkan. Dalam penelitian Nurhayati (2013) pendekatan pendidikan matematika realistik mampu meningkatkan keterampilan berpikir ktitis matematis peserta didik SMP, maka akan berlaku sama untuk peserta didik SD

Berdasarkan uraian di atas, penulis ingin memperbaiki hasil belajar peserta didik dalam pembelajaran matematika dengan meningkatkan keterampilan berpikir kritis pada geometri dengan pendekatan pendidikan matematika realistik di kelas IV SDN I Pule Kecamatan Pule Kabupaten Trenggalek.

Berdasarkan uraian yang dikemukakan, maka rumusan masalah dalam penulisan ini adalah "Bagaimanakah peningkatkan keterampilan berpikir kritis pada pembelajaran geometri dengan pendekatan pendidikan matematika realistik di kelas IV SDN I Pule Kecamatan Pule Kabupaten Trenggalek?"

\section{METODE}

Penelitian ini adalah Penelitian Tindakan Kelas (PTK) untuk meningkatkan kemampuan berpikir berpikir kritis pada geometri dengan pendekatan pembelajaranan matematika realistik di kelas IV SDN 1 Pule Kecamatan Pule Kabupaten Trenggalek. Penelitian ini juga termasuk penelitian deskriptif kuantitatif, karena menggambarkan bagaimana proses pembelajaran matematika dengan pendekatan matematika realistik dan bagaimana hasil yang diinginkan dapat tercapai.

Penelitian ini menggunakan model penelitian yang dikemukakan oleh Kemmis dan Mc Taggart yang bertujuan untuk meningkatkan kemampuan peserta didik di kelas, serta menentukan solusi terhadap masalah pembelajaran di kelas melalui penelitian yang dilakukan secara bersiklus. Sebagaimana dinyatakan oleh Kemmis dan Mc Taggart (dalam Riyanto, 2007:141) penelitian tindakan ini menggunakan prosedur kerja dengan siklus spiral. Dalam satu siklus terdapat empat tahap yang terdiri atas perencanaan, aksi/tindakan, observasi, dan refleksi. 
Dalam penelitian ini, data-data yang terkumpul dianalisis secara deskriptif kuantitatif. Pengumpulan data dilakukan dengan menggunakan Tes Keterampilan Berpikir Kritis (TKBK), Tes Hasil Belajar (THB), observasi aktivitas guru dan peserta didik selama proses KBM, dan angket respon peserta didik.

\section{HASIL DAN PEMBAHASAN}

Berdasarkan hasil validasi ahli menunjukkan bahwa perangkat pembelajaran yang terdiri dari RPP, LKPD, soal TKBK, dan soal THB, ditinjau dari aspek-aspek penilaian perangkat rata-rata masuk dalam kategori baik, cukup valid dan layak digunakan dengan sedikit revisi. Revisi dilakukan berdasarkan masukan atau saran dan diskusi dengan para ahli. Setelah direvisi soal THB diujicobakan untuk mengetahui validitas butir soal dan reliabilitas soal. Hasil uji coba tersebut menunjukkan bahwa rata-rata validitas butir soal cukup tinggi dan dinyatakan valid atau layak digunakan tanpa revisi. Sedangkan hasil reliabilitas soal masuk dalam kategori reliabilitas tinggi. Dengan demikian soal THB dapat digunakan dalam penelitian untuk mengukur hasil belajar peserta didik.

Berdasarkan hasil observasi guru selama KBM menunjukkan bahwa pembelajaran geometri dengan pendekatan PMR dilaksanakan sesuai dengan langkah-langkah pembelajaran dalam RPP. Skor yang diperoleh guru dalam setiap aspek yang diamati berkisar antara 4 dan 5 dengan rata-rata 4,6 atau $91,8 \%$ pada siklus I dan meningkat menjadi 4,75 atau 94,7\% pada siklus II. Berdasarkan kriteria penilaian aktivitas guru yang telah ditetapkan, hasil observasi aktivitas guru pada siklus I dan II masuk dalam kategori sangat baik karena berada pada rentang nilai $86 \%$ - $100 \%$ dan dinyatakan tuntas karena telah mencapai indikator keberhasilan dalam PTK ini.

Sedangkan hasil observasi terhadap peserta didik selama KBM menunjukkan bahwa aktivitas peserta didik mencapai kategori aktif karena berada dalam rentang nilai $76 \%-85 \%$, yakni $78,5 \%$ pada siklus I dan meningkat menjadi $85 \%$ pada siklus II.

Peningkatan tersebut membuktikan bahwa pembelajaran geometri dengan pendekatan PMR mampu meningkatkan keaktifan peserta didik dalam belajar.

Berdasarkan hasil penelitian pada studi awal, siklus I dan II keterampilan berpikir kritis peserta didik meningkat setelah menerapkan pendekatan
PMR dalam pembelajaran geometri. Hal ini dikarenakan dalam KBM tidak terpancang pada buku paket saja, tetapi diberikan permasalahan yang kontekstual yang disajikan dalam LKPD dan soal TKBK, serta dalam KBM lebih mengutamakan interaksi peserta didik dalam diskusi kelompok maupun diskusi kelas. Hasil penelitian keterampilan berpikir kritis peserta didik disajikan dalam tabel 5.1 berikut.

Tabel 5.1 Perbandingan Hasil TKBK

\begin{tabular}{cccc}
\hline No & Tes & $\begin{array}{c}\text { Rata-rata } \\
\text { hasil tes } \\
(\%)\end{array}$ & Keterangan \\
\hline 1. & Studi & 53 & Belum tuntas \\
2. & Siklis I & 61 & Belum tuntas \\
3. & Siklus II & 76 & Tuntas \\
\hline
\end{tabular}

Berdasarkan tabel di atas menunjukkan bahwa Penelitian Tindakan Kelas (PTK) telah berhasil meningkatkan keterampilan berpikir kritis peserta didik, karena telah berhasil mencapai indikator keberhasilan yang ditetapkan dan dinyatakan tuntas pada siklus II. Terbukti rata-rata hasil TKBK pada saat studi awal 53\% meningkat menjadi $61 \%$ pada siklus I, dan meningkat kembali menjadi $76 \%$ pada siklus II.

Keberhasilan penelitian peningkatan keterampilan berpikir kritis ini juga dibuktikan dari peningkatan pula kriteria berpikir kritis pada setiap TKBK yang diberikan. Kriteria berpikir kritis tersebut antara lain: focus, reason, inference, situation, clarity, dan overview (Ennis, 1995:4-8). Peningkatan tersebut dapat kita lihat pada grafik 5.1

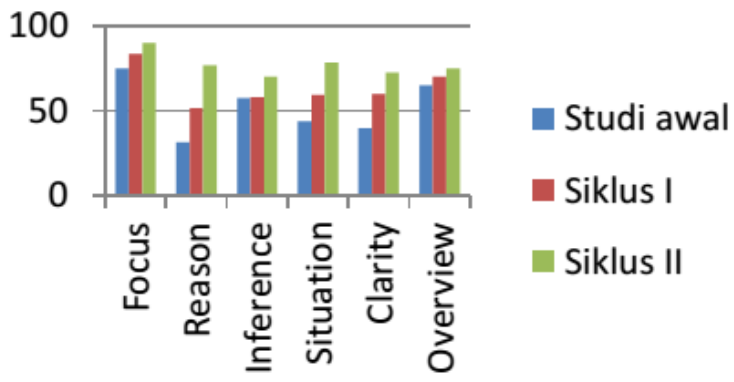

Grafik 5.1 Perbandingan Kriteria berpikir kritis Hasil TKBK

Berdasarkan data hasil belajar peserta didik menunjukan bahwa hasil belajar peserta didik mengalami peningkatan pada siklus II jika dibandingkan dengan siklus I, yakni $74,0 \%$ menjadi $86,5 \%$. Peserta didik yang memperoleh nilai $\geq$ 
KKM juga meningkat, yakni yang semula $60 \%$ dari 20 peserta didik pada siklus I meningkat menjadi $90 \%$. Sedangkan yang < KKM menurun dari $40 \%$ pada siklus I menjadi $10 \%$ pada siklus II. Karena hasil belajar peserta didik tersebut telah mencapai indikator keberhasilan yang ditetapkan, yakni lebih dari $80 \%$ peserta didik yang mencapai KKM dan nilai rata-rata/ketuntasan klasikal $\geq 75 \%$, maka hasil belajar pada siklus II dinyatakan tuntas.

Berdasarkan data hasil penelitian angket respon peserta didik menunjukkan bahwa pembelajaran geometri dengan pendekatan PMR mendapat respon positif dari peserta didik. Jika dibandingkan dengan respon peserta didik pada siklus I, respon positif pada siklus II mengalami peningkatan. Peserta didik yang memberi respon sangat setuju meningkat dari $65,5 \%$ pada siklus I menjadi $67,5 \%$ pada siklus II dan yang merespon setuju meningkat dari $31,0 \%$ pada siklus I menjadi $32,5 \%$ pada siklus II. Sedangkan respon kurang setuju dan tidak setuju, yang semula 2,0\% dan 1,5\% pada siklus I, turun menjadi $0,0 \%$ pada siklus II.

\section{PENUTUP}

Berdasarkan hasil penelitian dan pembahasan, dapat disimpulkan bahwa terjadi peningkatan keterampilan berpikir kritis pada pembelajaran geometri dengan pendekatan PMR di kelas IV SDN 1 Pule Kecamatan Pule Kabupaten Trenggalek. Peningkatan keterampilan berpikir kritis peserta didik ditunjukan oleh peningkatan hasil tes keterampilan berpikir kritis pada setiap tahap penelitian, mulai dari studi awal sampai siklus II; yakni, 53,0\% pada studi awal menjadi 61,0\% pada siklus I dengan kriteria cukup kritis, dan dari siklus I kembali meningkat menjadi 76,4\% dengan kriteria kritis. Keterampilan berpikir kritis peserta didik pada siklus II ini telah mencapai indikator keberhasilan yakni $\geq 75 \%$ dengan kriteria berpikir kritis menunjukkan tingkat kritis.

Sedangkan saran yang dapat disampaikan berdasarkan hasil penelitian di atas adalah:

1. Diharapkan dalam pembelajaran geometri guru menerapkan pendekatan PMR karena terbukti mampu meningkatkan keterampilan berpikir kritis dan hasil belajar peserta didik.

2. Diharapkan dalam pembelajaran geometri guru menerapkan pendekatan PMR karena terbukti mampu meningkatkan aktivitas peserta didik.

3. Diharapkan dalam pembelajaran geometri guru menerapkan pendekatan PMR karena
KBM menjadi lebih bermakna, yakni lebih menarik, lebih menantang, dan lebih bermanfaat bagi peserta didik.

\section{DAFTAR PUSTAKA}

Amin, Siti Maghfirotun. 2015. Belajar Matematika? Yes!!!. Makalah Dipresentasikan pada Seminar Nasional Matematika Universitas Adi Buana Surabaya. Tanggal 30 Mei 2015.

Anggraini, Valentine Luky. 2012. Profil Berpikir Kritis Siswa dalam Pembelajaran Inkuiri dengan Topik Grafik Fungsi Kuadrat Berbantuan Winplot Ditinjau Dari Kemampuan Matematika. Makalah Komprehensif pada PPS UNESA Surabaya: tidak diterbitkan.

Appelbaum, Mark \& Leinking, Roza. 2007. Looking Back At The Beginning: Critical Thinking in Solving Unrealistic Problems. (Online). http://www.math.umt.edu.tmme vol 4 no 2 p.258. diakses tanggal 7 Juli 2014.

Arends, Richard I. 2008. Learning to Teach Seventh Edition. New York: Mc Graw-Hill.

Arifin, Zaenal. 2010. Membangun Kompetensi Pedagogis Guru Matematika. Surabaya: Lentera Cendekia.

Arikunto, Suharsimi. 2006. Prosedur Penelitian Suatu Pendekatan Praktik. Jakarta:Rineka cipta

Arikunto, Suharsimi, dkk. 2010. Penelitian Tindakan Kelas. Jakarta: PT Bumi Aksara.

Arikunto, Suharsimi. 2013. Dasar-Dasar Evalusi Pendidikan. Jakarta: PT Bumi Aksara.

Bestari, Anindya Dian. 2012. Pengaruh Kemampuan Berpikir Kritis Siswa Kelas VIII SMPN 1 Margorejo dengan Model Numbered Head Tugether (NHT) Berbantuan Hands On Activity terhadap Hasil Belajar Siswa pada Materi Pokok Lingkaran. Tesis pada PPS UNS Semarang: tidak diterbitkan.

BSNP. 2006. Standar Kompetensi dan Kompetensi Dasar SD/MI. Jakarta: BSNP.

Budi, Rahmad Ramelan Setia. 2008. Penerapan Pendidikan Matematika Realistik Indonesia melalui Penggunaan Alat Peraga Paktik Miniatur Tandon Air terhadap Hasil Belajar Siswa Di Kelas X SMA Negeri Kota Manna. Jurnal Pendidikan Matematika, Vol. 2. No.1. 
Bushaw, D. W. (1998). Preparing Teachers for Realistic Mathematics Education. The College Mathematics Journal, 29(1), 74. Retrieved from http://search.proquest.com/docview/20393 2009? accountid=139588. diakses tanggal 18 Desember 2014.

Copeland, Richard W. 1976. Mathematics and The Elementary Teacher $3^{\text {rd }}$ Edition. Philadelphia, London, Toronto: W B Saunders Company.

Daryanto, \& Tasrial. 2012. Konsep Pembelajaran Kreatif. Yogyakarta: Gava Media.

Djamarah, Syaiful. 2006. Strategi Belajar Mengajar. Jakarta: PT Rineka Cipta.

Ennis, Robert H. 1995. Critikal Thinking. New Jersey: Prentice-Hall.

Ennis, Robert H. 2000. An Outline Of Goals For Critical Thinking Curuculum and Its Assesment. (Online). http://facullty.ed.uiue.edu/rhennis. diakses tanggal 18 Juli 2014.

Ermayanti. 2014. Penerapan Pembelajaran Matematika Realistik untuk Meningkatkan Kemampuan Berpikir Kreatif. Tesis pada PPS UNESA Surabaya: tidak diterbitkan.

Fathani, A. H. 2009. Matematika Hakikat dan Logika. Jogjakarta: Ar-Ruzz Media Group.

Fiantika, Feny Rita. 2005. Pembelajaran Matematika Ralistik untuk Pokok Bahasan Pencerminan dan Simetri. Tesis pada PPS UNESA Surabaya: tidak diterbitkan

Filsaime, Dennis K. 2008. Menguak Rahasia Berpikir Kritis dan Kreatif. Jakarta: Prestasi Pustaka.

Fisher, Alec. 2009. Berpikir Kritis Sebuah Pengantar. Jakarta: Erlangga.

Gravemeijer, K. P. E. 1994. Developing Realistic Mathematics Education. Freudhental: Institute Ultrecht.

Hadi, Sutarto. 2005. Pendidikan Matematika Realistik dan Implementasinya. Banjarmasin: Tulip Banjarmasin.

Hadis, Abdul \& Nurhayati B. 2010. Psikologi dalam Pendidikan. Bandung: Alfabeta.

Hamalik, Oemar. 2006. Proses Belajar Mengajar. Jakarta: Bumi Aksara.

Hanafiah, Nanang \& Cucu Suhana. 2010. Konsep Strategi Pembelajaran. Bandung: PT Refika Aditama.
Heruman. 2010. Model Pembelajaran Matematika di Sekolah Dasar. Bandung: PT Rosda Karya.

Johnson, Elaine B. 2002. Contextual Teaching and Learning: What It Is And Why It's Here To Stay. California: Corwin Press.

Kerami, Djati \& Cormentyna Sitanggang. 2003. Kamus Matematika. Jakarta: Balai Pustaka.

Muhsetyo, Gatot, dkk. 2011. Pembelajaran Matematika SD. Jakarta: Universitas Terbuka.

Nurhayati, Yetty. 2013. Meningkatkan Kemampuan Representasi dan Berpikir Kritis Matematis Siswa SMP melalui Pendekatan Pendidikan Matematika Realistik. Tesis pada PPS UPI Bandung: tidak diterbitkan.

Nur, Mohamad, dkk. 2008. Teori Pembelajaran Kognitif. Surabaya: Unesa Pusat Sains dan Matematika Sekolah.

Nur, Mohamad, \& Prima Retno Wikandari. 2008. Pengajaran Berpusat Kepada Siswa dan Pendekatan Konstruktivis dalam Pengajaran. Surabaya: Unesa Pusat Sains Dan Matematika Sekolah.

Ratumanan, T. G. \& Theresia Laurens. 2011. Penilaian Hasil Belajar pada Tingkat Satuan Pendidikan Edisi 2. Surabaya: unesa university press.

Reys, Robert, Mary M. L., Diana V. L., \& Nancy L. S. 2009. Helping Children Learn Mathematics. United States of America: Wiley.

Riyanto, Yatim. 2007. Metodologi Penelitian Pendidikan Kualitatif dan Kuantitatif. Surabaya: Unesa University Press.

Riyanto, Yatim. 2009. Paradigma Baru Pembelajaran: Sebagai Referensi Bagi Guru/Pendidik dalam Implementasi Pembelajaran Yang Efektif dan Berkualitas. Jakarta: Kencana Prenada Media Group.

Ruseffendi, E. T. 1988. Pengantar Kepada Membantu Guru Mengembangkan Kompetensi dalam Pengajaran Matematika Untuk Meningkatkan CBSA. Bandung: Tarsito.

Santrock, W. J. 2008. Psikologi Pendidikan. Jakarta: Kencana Prenada Media Group.

Siswono, Tatag Yuli Eko. 2008. Model Pembelajaran Matematika Berbasis Pengajuan dan Pemecahan Masalah untuk 
Meningkatkan Kemampuan Berpikir Kreatif. Surabaya: Unesa University Press.

Smith-Blair, N., \& Neighbors, Marianne,EdD., R.N. (2000). Use of the critical thinking disposition inventory in critical care orientation. The Journal of Continuing Education in Nursing, 31(6), 251-6. Retrieved from http://search.proquest.com/docview/22332 3258? accountid $=139588$

Soedjadi, R. 1999. Dasar-Dasar Matematika. Surabaya: IKIP Surabaya Press.

Soedjadi, R. 2007. Masalah Kontekstual Sebagai Batu Sendi Matematika Sekolah. Surabaya: Unesa Pusat Sains dan Matematika Sekolah.

Solso. Robert L. 2008. Psikologi Kognitif. Jakarta: Erlangga.

Somakin. 2011. Peningkatan Kemampuan Berpikir Kritis Matematis Siswa Sekolah Menengah Pertama dengan Penggunaan Pendidikan Matematika Realistik. Jurnal PenelitianPendidikan Forum MIPA, Vol. 14. No. 1

Soviawati, Evi. 2011. Pendekatan Matematika Realistik (PMR) untuk Meningkatkan Kemampuan Berpikir Siswa di Tingkat Sekolah Dasar. Jurnal Penelitian Pendidikan, Edisi Khusus No.2, ISSN 1412-565X.

Streefland, Leen. 1991. Realistic Mathematics Education in Primary School. The Netherlands: Freudenthal Institute.

Sudjana. 1984. Dasar-Dasar Proses Belajar Mengajar. Bandung: Sinar Baru.

Suparno, P. 1997. Filsafat Konstruktivisme dalam Pendidikan. Jakarta: Kanisius.

Trianto. 2011. Model-Model Pembelajaran Inovatif Berorientasi Konstruktivistik. Jakarta: Prestasi Pustaka.

Unal, Z. A., \& Ipwk, A. S. 2009. The Effect of Realistic Mathematics Education on 7th Grade Students' Achievements in Multiplication of Integers. Egitim Ve Bilim, 34(152), 60. Retrieved from http://search.proquest.com/docview/10098 42163 ?accountid $=139588$. diakses tanggal 18 Desember 2014.

Warli. 2008. Pembelajaran Matematika Realistik Materi Geometri Kelas IV MI. http://ejournal.unirow.ac.id/ojs/files/journa
ls/2/articles/4/public/JURNAL-WARLI4.pdf

Wijaya, Ariyadi. 2012. Pendidikan Matematika Realistik Suatu Alternatif Pendekatan Pembelajaran Matematika. Yogyakarta: Graha Ilmu.

Winataputra, Udin S, dkk. 2008. Teori Belajar dan Pembelajaran. Jakarta: Universitas Terbuka. 